\title{
PERHITUNGAN HARGA POKOK PRODUKSI DENGAN METODE HARGA POKOK PESANAN PADA CV MITRA BISNIS ANDA
}

\author{
Zidna Farihah Hayat, Sulistiyo \\ Prodi Akuntansi, Jurusan Akuntansi, Politeknik Negeri Semarang \\ Jl. Prof. H. Sudarto, S.H., Tembalang Semarang 50275
}

\begin{abstract}
The aim of this research to identify the elements of cost of production and calculate the cost of production of CV Mitra Bisnis Anda with the Cost of Job Order Method. Writing method used is descriptive and exposition method. Meanwhile, the exposition describes the classification of costs according to the method of job order and calculation of the cost of production for each product. The method of analysis used is comparative analysis, that is by comparing the calculation of cost of production by the job order method with the cost of production by the company.

Based on the calculation and analysis that has been done, there is a difference in cost of production amounted to Rp. 33.137,53.; for the springbedsandaran kotak is Rp. 22.864,13.-, while for the springbedsandaran konde isRp. 10.273,4.-. The difference arises because there are differences in the classification of production costs, the company does not include depreciation cost because the company has not shrunk its assets, nor does not include the cost of repairs and maintenance when calculating the factory overhead costs.
\end{abstract}

Keyword : Cost of Production, Job Order Cost, Factory Overhead Cost

\begin{abstract}
Abstrak: Penelitian ini bertujuan untuk mengidentifikasi unsur-unsur biaya produksi dan menghitung biaya produksi CV Mitra Bisnis Anda dengan Metode Harga Pokok Pesanan. Metode penulisan yang digunakan adalah metode deskriptif dan eksposisi. Sedangkan eksposisi menggambarkan klasifikasi biaya sesuai dengan metode job order dan perhitungan biaya produksi untuk setiap produk. Metode analisis yang digunakan adalah analisis komparatif, yaitu dengan membandingkan perhitungan biaya produksi dengan metode job order dengan biaya produksi oleh perusahaan.

Berdasarkan perhitungan dan analisis yang telah dilakukan, terdapat selisih biaya produksi sebesar Rp. 33.137.53.-, untuk springbed sandaran kotak adalah Rp. 22.864,13.-, sedangkan untuk springbed sandaran konde adalah Rp. 10.273.4.Perbedaan tersebut timbul karena ada perbedaan dalam klasifikasi biaya produksi, perusahaan tidak memasukkan biaya penyusutan karena perusahaan belum mengurangi asetnya, juga tidak termasuk biaya perbaikan dan pemeliharaan saat menghitung biaya overhead pabrik.
\end{abstract}

Kata kunci: Biaya Produksi, Biaya Pesanan Pekerjaan, Biaya Overhead Pabrik 


\section{PENDAHULUAN \\ Latar Belakang}

Perusahaan didirikan mempunyai tujuan yang telah ditentukan, sebab tujuan merupakan titik inti bagi segala pemikiran dalam perusahaan dan tujuan juga memberikan arah bagi kegiatan dan cara untuk mengukur efektifitas kegiatan perusahaan. Tujuan perusahaan pada umumnya antara lain untuk mendapat laba secara maksimal, untuk menampung tenaga kerja dan untuk membantu pemerintah dalam hal pajak. Salah satu tujuan perusahaan tersebut yaitu untuk mendapatkan laba secara maksimal yang digunakan untuk mempertahankan kelangsungan hidup dan perkembangan perusahaan. Agar tujuan tersebut dapat terwujud, manajemen perusahaan selalu berusaha untuk mengendalikan biaya produksi dari barang yang dihasilkan. Perusahaan dituntut untuk menghasilkan barang dan jasa yang berkualitas tetapi dengan harga yang terjangkau oleh masyarakat serta memperoleh keuntungan yang cukup. Keuntungan itu tetap diperoleh bila perusahaan berhasil menjual hasil produksinya dengan harga yang tepat, sehingga dapat menutup biaya-biaya yang telah dikeluarkan, memperoleh laba yang diinginkan dan kompetitif dengan harga jual dari perusahaan lain.

Salah satu cara untuk menentukan harga jual, adalah menggunakan harga pokok produksi. Apabila penentuan harga pokok produksi tidak tepat, maka harga jualnya juga tidak tepat, bisa terlalu tinggi atau terlalu rendah. Hal ini dapat mengakibatkan kerugian bagi perusahaan karena tidak dapat menutup biaya yang digunakan selama proses produksi.

Penentuan harga pokok produksi yang kurang tepat akan mengakibatkan nilai persediaan yang ada di neraca pada kelompok aktiva menjadi tidak tepat. Selain itu, pada laporan laba rugi persediaan dan harga pokok produksi yang kurang tepat akan mempengaruhi harga pokok penjualan dan laba yang dihasilkan perusahaan. Perhitungan harga pokok produksi yang kurang tepat akan sangat mempengaruhi pengambilan keputusan manajemen selama periode tersebut, misal pengambilan keputusan untuk menentukan harga pokok produksi suatu produk, dengan menentukan harga pokok produksi pesanan maka perusahaan dapat mengetahui biaya produksi yang akan dikeluarkan. Perusahaan dalam menentukan harga jual dari suatu pesanan harus sesuai dengan biaya produksi yang telah dikeluarkan untuk memproduksi pesanan tersebut dalam mendapatkan laba yang diinginkan oleh perusahaan dengan optimal, karena harga jual yang dibebankan kepada pemesan ditentukan oleh besarnya biaya produksi yang dikeluarkan untuk memproduksi pesanan tersebut.

CV Mitra Bisnis Anda merupakan perusahaan yang bergerak di bidang mebel. Produk yang dihasilkan adalah springbed. Perusahaan tersebut memproduksi sesuai pesanan dari pelanggan. CV Mitra Bisnis Anda dalam menghitung harga pokok produksi masih terdapat biaya-biaya yang tidak diperhitungkan. Sehingga, harga pokok produksi yang telah ditetapkan menjadi kurang tepat.

\section{Rumusan Masalah}

Dari latar belakang yang telah diuraikan sebelumnya, maka dapat dirumuskan permasalahan sebagai berikut :

1) Bagaimana perhitungan harga pokok produksi dengan metode harga pokok pesanan pada CV Mitra Bisnis Anda bulan Januari 2017? 2) Bagaimana perbandingan perhitungan harga pokok produksi CV Mitra Bisnis Anda dengan perhitungan harga pokok produksi dengan metode pesanan?

\section{METODE PENELITIAN}

Jenis dan Sumber Data

Data Kuantitatif, berupa biaya bahan baku dan penolong, biaya 
tenaga kerja, biaya overhead pabrik. Data Kualitatif, berupa gambaran umum dan sejarah singkat perusahaan, struktur organisasi, proses produksi, serta data lain yang mendukung. Data Sekunder, berupa data pemakaian biaya, baik biaya bahan baku, biaya tenaga kerja, maupun biaya overhead pabrik.

\section{Metode Pengumpulan Data}

1) Wawancara, data yang diperoleh adalah proses produksi, dan gambaran umum perusahaan. 2) Studi Pustaka. 3) Observasi, observasi dilakukan pada bagian produksi yaitu dengan melihat dan mengamati proses produksi yang dilakukan CV Mitra Bisnis Anda.

\section{Metode Penulisan}

1) Deskriptif, yaitu meliputi uraian mengenai gambaran umum dan sejarah singkat perusahaan, visi-misi, struktur organisasi, tugas dan wewenang.

2) Eksposisi, yaitu menguraikan tentang perhitungan harga pokok produksi dengan metode pesanan pada CV Mitra Bisnis Anda.

\section{Metode Analisis Data}

1) Analisis Komparatif, yaitu dengan membandingkan hasil perhitungan harga pokok produksi yang dilakukan perusahaan dengan perhitungan harga pokok produksi dengan metode harga pokok pesanan.

\section{HASIL DAN PEMBAHASAN \\ Sejarah Singkat Perusahaan}

CV Mitra Bisnis Anda merupakan perusahaan manufaktur yang bergerak dalam bidang pembuatan springbed. Perusahaan ini didirikan oleh Bapak Simon pada tanggal 12 April 1990. Pada awalnya, perusahaan ini merupakan distributor springbed di Jawa Tengah. Barang - barang dikirim dari Jawa Barat kemudian di distribusikan di Jawa Tengah. Seiring berjalannya waktu, pada bulan Mei 2014 perusahaan memproduksi sendiri divan dan sandaran springbed, karena apabila produksi di pindah ke
Jawa Tengah maka lebih efisien, bahan baku yang mudah didapat serta ongkos angkut yang relatif lebih murah. Sedangkan, matras yang digunakan untuk membuat springbed masih dikirim dari Jawa Barat.

CV Mitra Bisnis Anda berlokasi di Semarang, tepatnya di Jalan Durian Utara II Kecamatan Banyumanik Semarang. Produk yang dihasilkan oleh CV Mitra Bisnis Anda adalah springbed sandaran kotak dan springbed sandaran konde. Perusahaan telah melayani pesanan dari Jawa Tengah maupun Jawa Timur.

\section{Biaya Bahan Baku}

Berdasarkan perhitungan yang telah dilakukan, pemakaian biaya bahan baku untuk produk springbed sandaran kotak sebesar $\mathrm{Rp}$. 22.534.875, sedangkan pemakaian biaya bahan baku untuk produk springbed sandaran konde sebesar Rp. 41.686.375. Sehingga total pemakaian biaya bahan baku pada bulan Januari 2017 sebesar Rp. 64.221.250.

\section{Biaya Tenaga Kerja Langsung}

Pemakaian biaya tenaga kerja langsung untuk produk springbed sandaran kotak adalah sebesar $\mathrm{Rp}$. 25.600.000, dimana pada bagian perakitan sebesar Rp.2.560.000, bagian penjahitan sebesar Rp.5.120.000, dan bagian finishing sebesar Rp. 17.920.000. Sedangkan pemakaian biaya tenaga kerja langsung untuk produk springbed sandaran konde adalah sebesar Rp.50.320.000, dimana bagian perakitan sebesar Rp.5.440.000, bagian penjahitan sebesar Rp.9.520.000, dan bagian finishing sebesar Rp.35.360.000. Sehingga total pemakaian biaya tenaga kerja langsung sebesar Rp.75.920.000.

\section{Biaya Overhead Pabrik}

Biaya overhead pabrik yang dibebankan untuk masing-masing produk adalah, untuk produk springbed sandaran kotak sebesar Rp.27.178.112, dan untuk produk 
springbed sandaran konde sebesar Rp.53.310.912. Sehingga total biaya overhead pabrik bulan Januari 2017 adalah Rp.80.489.024.

\section{Produk Selesai}

Berdasarkan perhitungan harga pokok produksi metode pesanan, harga pokok produksi per unit untuk produk springbed sandaran kotak adalah Rp.390.222,73, sedangkan springbed sandaran konde adalah Rp.473.346,21.

Sedangkan perhitungan harga pokok produksi menurut perusahaan, harga pokok produksi per unit untuk produkspringbed sandaran kotak adalah Rp. 367.358,60, dan untuk produk springbed sandaran konde adalah Rp.463.072,81.
Sehingga terdapat selisih perhitungan harga pokok produksi antara metode pesanan dan perusahaan, dimana selisih harga pokok produksi untuk produk springbed sandaran kotak sebesar Rp.22.864,13, dan untuk produk springbed sandaran konde sebesar Rp.10.273,4.

\section{Kartu Harga Pokok Pesanan}

Kartu harga pokok pesanan ini dibuat berdasarkan biaya yang timbul selama kegiatan produksi. Kartu harga pokok produksi untuk masingmasing pesanan pada CV Mitra Bisnis Anda bulan Januari 2017 dapat dilihat pada tabel 1 berikut ini:

Tabel 1. Kartu Harga Pokok Pesanan Springbed Sandaran Kotak

\begin{tabular}{|c|c|c|c|c|}
\hline $\begin{array}{l}\text { Nama } \\
\text { Jumlah }\end{array}$ & $\begin{array}{l}\text { KAI } \\
\text { luk : Springbed } \\
\text { sanan } \quad: 193\end{array}$ & $\begin{array}{l}\text { CV Mitra Bis } \\
\text { HARGA PO } \\
\text { daran Kotak } \\
\text { t }\end{array}$ & $\begin{array}{l}\text { ais Anda } \\
\text { KOK PESANAN }\end{array}$ & \\
\hline & Bahan Baku & $\begin{array}{r}\text { Biaya } \\
\mathrm{L}\end{array}$ & $\begin{array}{l}\text { enaga Kerja } \\
\text { ngsung }\end{array}$ & $\begin{array}{c}\text { Biaya Overhead } \\
\text { Pabrik }\end{array}$ \\
\hline $\begin{array}{l}\text { Jenis } \\
\text { Bahan }\end{array}$ & Jumlah (Rp) & Bagian & Jumlah (Rp) & Jumlah (Rp) \\
\hline & Rp. 22.534.875 & $\begin{array}{l}\text { Perakitan } \\
\text { Penjahitan } \\
\text { Finishing }\end{array}$ & $\begin{array}{l}\text { Rp. 2.560.000 } \\
\text { Rp. 5.120.000 } \\
\text { Rp. } 17.920 .000\end{array}$ & Rp. 27.18.112 \\
\hline & Rp. 22.534.875 & & Rp. 25.600.000 & Rp. 27.178.112 \\
\hline $\begin{array}{l}\text { Total B } \\
\text { Harga }\end{array}$ & $\begin{array}{l}\text { Produksi : } \\
\text { ya Bahan Baku } \\
\text { ya Tenaga Kerja } \\
\text { ya Overhead Pal } \\
\text { rga Pokok Produ } \\
\text { antitas Produksi } \\
\text { ok Produksi per }\end{array}$ & $\begin{aligned} & : \text { Rp. } \\
\text { ngsung } & : \text { Rp. } \\
& : \text { Rp. } \\
& : 193 \\
& : \text { Rp. }\end{aligned}$ & $\begin{array}{l}2.534 .875 \\
5.600 .000 \\
: \underline{\text { Rp. } 27.178 .11} \\
5.312 .987 \\
\text { Set } \\
99.222,73\end{array}$ & \\
\hline
\end{tabular}

Sumber : Data yang diolah, 2017 


\begin{tabular}{|c|c|c|c|c|}
\hline $\begin{array}{l}\text { Nama } \\
\text { Jumlah }\end{array}$ & $\begin{array}{l}\text { KAI } \\
\text { uk : Springbed } \\
\text { sanan : } \quad \text { 307 }\end{array}$ & $\begin{array}{l}\text { CV Mitra Bis } \\
\text { HARGA PO } \\
\text { daran Konde }\end{array}$ & $\begin{array}{l}\text { nis Anda } \\
\text { KOK PESANAN }\end{array}$ & \\
\hline & Bahan Baku & $\begin{array}{r}\text { Biaya } \\
\mathrm{L} \\
\end{array}$ & $\begin{array}{l}\text { Tenaga Kerja } \\
\text { angsung }\end{array}$ & $\begin{array}{c}\text { Biaya Overhead } \\
\text { Pabrik }\end{array}$ \\
\hline $\begin{array}{l}\text { Jenis } \\
\text { Bahan }\end{array}$ & Jumlah (Rp) & Bagian & Jumlah (Rp) & Jumlah (Rp) \\
\hline & Rp. 41.686.375 & $\begin{array}{l}\text { Perakitan } \\
\text { Penjahitan } \\
\text { Finishing }\end{array}$ & \begin{tabular}{|l|} 
Rp. 5.440 .000 \\
Rp. 9.520 .000 \\
Rp. 35.360 .000
\end{tabular} & Rp. 53.310.912 \\
\hline & Rp. 41.686.375 & & Rp. 50.320 .000 & Rp. 53.310.912 \\
\hline $\begin{array}{l}\text { Total B } \\
\\
\text { Harga } \\
\text { Kuanti } \\
\text { Harga }\end{array}$ & $\begin{array}{l}\text { Produksi : } \\
\text { ya Bahan Baku } \\
\text { ya Tenaga Kerja } \\
\text { ya Overhead Pal } \\
\text { ok Produksi } \\
\text { Produksi } \\
\text { ok Produksi per }\end{array}$ & $\begin{aligned} & : R p . \\
\text { gssung } & : \mathrm{Rp} . \\
& : \mathrm{Rp} . \\
& : 307 \\
& : \mathrm{Rp} .\end{aligned}$ & $\begin{array}{l}1.686 .375 \\
50.320 .000 \\
\quad: \underline{R p .53 .310 .91} \\
145.317 .287 \\
\text { Set } \\
473.346,21\end{array}$ & \\
\hline
\end{tabular}

Sumber : Data yang diolah, 2017

\section{Biaya Overhead Pabrik Sesungguhnya}

Berikut adalah rincian BOPS pada bulan Januari 2017 :

1. Biaya bahan penolong, untuk produk springbed sandaran kotak sebesar Rp.19.589.072, sedangkan untuk produk springbed sandaran konde sebesar Rp.50.159.150.

2. Biaya tenaga kerja tidak langsung sebesar Rp.9.375.000.

3. Biaya listrik sebesar Rp. 888.057.

4. Biaya air sebesar Rp.300.000.

5. Biaya telepon sebesar Rp. 550.000.

6. Biaya reparasi dan pemeliharaan peralatan sebesar Rp.610.000, biaya reparasi dan pemeliharaan kendaraan sebesar Rp.535.000.

7. Biaya penyusutan kendaraan sebesar Rp.1.381.006,94, biaya penyusutan peralatan sebesar Rp.66.510,38.

\section{Selisih Biaya Overhead Pabrik}

Selisih BOP antara BOP

dibebankan dengan BOP sesungguhnya untuk produk springbed sandaran kotak adalah sebesar Rp.2.622.034 (menguntungkan). Sedangkan produk springbed sandaran konde terdapat selisih sebesar Rp.3.404.440 (tidak menguntungkan).

\section{KESIMPULAN}

Perbedaan perhitungan harga pokok produksi menurut perusahaan dengan perhitungan harga pokok produksi menurut metode pesanan disebabkan karena terdapat perbedaan dalam penggolongan biaya produksi, serta perbedaan dalam menghitung biaya overhead pabrik yang dibebankan pada setiap produk pesanan. Dalam menghitung biaya overhead pabrik, ada beberapa biaya yang tidak dimasukkan ke dalam perhitungan biaya overhead pabrik, seperti biaya penyusutan dan biaya reparasi dan pemeliharaan, sehingga biaya overhead pabrik menjadi tidak tepat. Apabila biaya overhead pabrik tidak tepat, maka harga pokok produksi juga menjadi tidak tepat. Apabila harga pokok produksi tidak tepat, maka harga pokok penjualan juga menjadi tidak tepat, sehingga apabila harga pokok penjualan tidak tepat, maka akan mempengaruhi laba 
yang akan didapatkan perusahaan di masa yang akan datang. Selain itu, perhitungan harga pokok produksi yang kurang tepat juga akan sangat mempengaruhi pengambilan keputusan manajemen selama periode tersebut.

\section{DAFTAR PUSTAKA}

Bustami dan Nurlela. 2006. Akuntansi Biaya Teori dan Aplikasi. Yogyakarta : Graha Ilmu.

Daljono. 2009. Akuntansi Biaya Penentuan Harga Pokok dan Pengendalian.

Edisi 3. Semarang: Badan Penerbit Universitas Diponegoro.

Handoko, Hani. 2009. Manajemen. Yogyakarta: BPFE.
Keraf, Gorys. 2004. Komposisi. Ende Flores: Nusa Indah.

Marzuki. 2000. Metodologi Riset. Yogyakarta: EKONISA.

Mulyadi. 2005. Akuntansi Biaya. Yogyakarta: UPP STIM YKPN.

Samryn, L.M. 2012. Akuntansi Manajemen Informasi Biaya untuk Mengendalikan

Aktivitas dan Investasi. Jakarta: Kencana Prenada Media Grup.

Supriyono. 2016. Akuntansi Biaya Pengumpulan Biaya dan Penentuan Harga Pokok. Yogyakarta: BPFE.

Wijaya, Tony. 2013. Metodologi Penelitian Ekonomi dan Bisnis.Yogyakarta: Graha Ilmu 